\title{
SMART LOCK DOOR MENGGUNAKAN AKSES E-KTP BERBASIS INTERNET OF THINGS
}

\author{
Moch Iqbal Tawakal ${ }^{1}$, Yudi Ramdhani ${ }^{2}$ \\ 1 Universitas Adhirajasa Reswara Sanjaya \\ e-mail: Iqbal.tawakal39@gmail.com \\ ${ }^{2}$ Universitas Adhirajasa Reswara Sanjaya \\ e-mail: yudi@ars.ac.id
}

\begin{abstract}
Abstrak
Tingkat kriminalitas dan keahlian para pencuri khususnya pencurian sebuah rumah elite yang semakin tinggi, membuat penulis memperoleh ide atau gagasan inovasi alat pengaman pintu rumah menggunakan Radio Frequency Identification (RFID) berbasis Internet of Things dengan menggunakan mikrokontroler NodeMcu Lolin V3 yang tentunya dengan sistem pengamanan yang tinggi dan juga dapat terkoneksi pada internet sehingga bisa juga di akses melalui smartphone android. Rancangan keamanan ini tidak mengandalkan mekanik sebagai interfacenya melainkan menggunakan perangkat elektronik yang cukup sulit untuk dibobol karena selain diperlukan pengetahuan mengenai elektronik, para pelaku kriminalitas juga harus memilki pengetahuan dibidang pemrograman dan teknologi informasi. Berbeda dengan kunci mekanik, kunci elektronik pada rancangan keamanan ini menggunakan Radio Frequency Identification (RFID) sebagai pembukanya dan juga dengan memanfaatkan teknologi Internet of Things (IoT) dengan menggunakan wireless yang terhubung pada aplikasi Smartphone Android. Berdasarkan hasil pengujian dapat disimpulkan bahwa simulasi alat pengaman pintu dapat beroperasi dengan baik, sesuai rancangan yang dibuat. RFID reader yang digunakan memiliki keamanan yang lebih terjamin,karena yang mana untuk mendaftarkan e-KTP dengan menggunakan aplikasi Blynk pada Smartphone Android, jadi tidak semua orang bisa mendaftarkan e-KTP, dan juga terdapat buzzer dan lampu LED, buzzer akan mengeluarkan suara dan lampu LED menyala hijau apabila kunci pintu dibuka sesuai dengan frekuensi $13,56 \mathrm{MHz}$ yang diletakkan dalam miniatur berbentuk rumah dengan tebal $2 \mathrm{~mm}$ dapat membaca UID e-KTP dengan jarak maksimal $2.5 \mathrm{~cm}$. Buzzer akan mengeluarkan suara dan lampu LED menyala merah apabila UID e-KTP tidak terdaftar pada alat tersebut. Solenoid Door Lock dapat membuka pengunci pintu apabila UID e-KTP sesuai dengan NodeMcu Lolin V3, solenoid akan mengunci kembali dalam waktu 5 detik.
\end{abstract}

Kata Kunci: RFID, e-KTP, Blynk, loT.

\section{Abstract}

The level of crime and the expertise of thieves, especially theft to an elite house, is getting higher, making the author get the idea or idea of innovating a door security device using Radio Frequency Identification (RFID) based on the Internet of Things using a NodeMcu Lolin V3 microcontroller which is of course with a security system that is high and can also be connected to the internet so that it can also be accessed via an Android smartphone. This security design does not rely on mechanics as its interface but uses electronic devices which are quite difficult to break because in addition to knowledge of electronics, criminals must also have knowledge in the fields of programming and information technology. Unlike the mechanical lock, the electronic lock in this security design uses Radio Frequency Identification (RFID) as the opening and also by utilizing Internet of Things (IOT) technology by using wireless connected to the Android Smartphone application. Based on the test results, it can be concluded that the simulation of the door safety device can operate properly, according to the design made. The RFID reader used has more guaranteed security, because which one is to register e-KTP using the Blynk application on an Android Smartphone, so not everyone can register e-KTP, and there is also a buzzer and LED light, the buzzer will emit a sound and a light The LED lights up green when the door lock is opened according to the $13.56 \mathrm{MHz}$ frequency which is placed in a miniature house-shaped with 
a thickness of $2 \mathrm{~mm}$ and can read UID e-KTP with a maximum distance of $2.5 \mathrm{~cm}$. The buzzer will emit a sound and the LED lights up red if the e-KTP UID is not registered on the device. Solenoid Door Lock can unlock the door if the UID e-KTP matches NodeMcu Lolin V3, the solenoid will lock again in 5 seconds.

Keywords: RFID, e-KTP, Blynk, IoT

\section{Pendahuluan}

Untuk mewujudkan visi Internet-ofThings (loT), banyak perangkat loT telah dikembangkan untuk meningkatkan setiap hari tinggal, di mana perangkat rumah pintar adalah yang paling popular yang kunci pintar bergantung pada smartphone untuk meringankan beban manajemen kunci fisik dan terus melacak pembukaan / penutupan pintu status, keamanan yang telah membangkitkan minat besar komunitas keamanan. Karena keamanan adalah yang paling penting untuk lingkungan IoT, kami mencoba menyelidiki keamanan loT dengan memeriksa keamanan kunci pintar. Secara khusus, kami fokus pada menganalisis keamanan kunci pintar (Ye, 2017).

Smart Home adalah tempat tinggal atau penghubung rumah jaringan komunikasi dengan peralatan listrik untuk menegndalikan dan memantau dari jarak jauh. Smart Home di pasar saat ini memiliki komunikasi yang cukup mahal dan antar perangkat menggunakan standar tertentu sehingga tidak mudah jika ingin melakukan lebih jauh pengembangan. Perangkat untuk mengakses rumah lingkungan dapat menggunakan perangkat seluler yang terhubung ke Internet nirkabel (Kusriyanto, 2017). Teknologi otomasi rumah membuat kehidupan manusia nyaman dan mewah. Itulah sebabnya hari ini setiap orang menginginkannya rumah pintar. Teknologi ini memberikan kontrol rumah perangkat serta interaksi yang aman dan cerdas antara personel di dalam dan di luar ruangan. Sistem control memberikan status tentang HIDUP atau MATI instrumen yang dipilih kepada pemilik rumah. Sistem ini juga dirancang untuk membantu, menyediakan, mendukung dan untuk memenuhi kebutuhan manusia di rumah. Sistem ini dimaksudkan untuk mengontrol peralatan listrik dirumah dan interaksi yang efektif dengan pengunjung dengan desain yang relatif murah, antarmuka yang ramah pengguna serta kemudahan dalam instalasi. Dengan menggunakan teknologi ini, konsumen dapat menghemat energi listrik dengan memonitor perangkat rumah secara teratur dan tepat sesuai penjadwalan perangkat (Kumar \& Pati, 2016).

Smart Lock Door bukanlah konsep baru. Namun dengan kemajuan teknologi, sistem ini juga telah menjadi lebih maju. Sistem kunci pintu pintar yang dibahas adalah pada dasarnya dirancang untuk operasi multi-mode seperti operasi multipengguna dan multi-level. Sistem seperti itu sangat banyak diperlukan di perumahan elit khusunya. Sistem ini juga memberikan fungsionalitas untuk pengguna umum, di mana pengguna tunggal berada berwenang untuk mengoperasikan kunci. Implementasi yang hemat biaya dengan fungsionalitas canggih dan antarmuka yang mudah digunakan membuat sistem ini sangat berguna (Kumar, 2016). Smart Lock Door adalah kunci pintu digital yang berfungsi berdasarkan mikrokontroler dan menyediakan multilevel keamanan dari teknologi tinggi yang diadaptasi oleh pencuri suara teknis. Pekerjaan yang diusulkan adalah membangun sistem yang menyediakan keamanan yang sederhana, cerdas dan terjangkau. Operasi mengunci dan membuka kunci pada pintu diamankan dan dikendalikan oleh sistem dengan bantuan modul RFID. Smart Lock memungkinkan pengguna untuk memonitor dari jarak jauh apakah ada yang mengakses sistem tersebut menggunakan teknologi wireless. Sistem ini dilengkapi dengan sensor RF (Radio Frequency) yang bertindak sebagai Intrusion Detection System (IDS). Sensor memonitor menutup dan membuka pintu dan mengirimkan peringatan kepengguna terdaftar jika terjadi pelanggaran keamanan (Patil \& Khilari, 2016).

Keamanan merupakan suatu hal yang harus sering kali diabaikan oleh kebanyakan orang dan menganggap sudah aman, namun nyatanya seseorang masih dapat kehilangan barang berharga miliknya. Contohnya pada ruangan yang keamanannya seringkali dianggap sudah baik oleh kebanyakan masyarakat hanya dengan mengunci pintu yang telah disediakan, namun sering juga masyarakat lupa mengunci pintu. Karena lupa mengunci 
pintu ruangan mengakibatkan seseorang kehilangan barang berharga miliknya. Perkembangan teknologi yang sudah semakin canggih sistem keamanan pintu harus mengikuti perkembangan jaman. Sistem keamanan pintu ruangan yang saat ini masih menggunakan metode konvensional dirasa kurang aman saat ini, walaupun sudah ada kamera cctv yang sudah digunakan untuk memantau ruangan (Wendanto, Salim, \& Putra, 2019). Keamanan pintu rumah yang ada selama ini masih konvensional menggunakan kunci pintu sebagai kunci dan sering terjadi pencurian dikarenakan sebagian besar pemilik rumah bekerja sehingga kurangnya pengawasan rumah oleh pemiliknya. Jadi kita memerlukan kunci yang lebih praktis dan efisien dan lebih banyak keamanan untuk kunci pintu (Padeli, Febriyanto, \& Suprayogi, 2019). Sistem keamanan rumah ini dibuat untuk pengaman rumah yang terjadi aktivitas keluar masuk orang sehingga meminimalisir hal-hal yang tidak diinginkan terjadi seperti pencurian. Alat ini memanfaatkan e-KTP sebagai identitas untuk masuk ke rumah sehingga keamanan dapat terjamin. Dengan adanya sistem keamanan menggunakan eKTP maka orang yang e-KTP nya belum terdeteksi oleh alat tidak dapat masuk (Ratih, Setiawan, \& Triono, 2019).

Radio Frequency Identification (RFID) merupakan teknologi yang mampu mengidentifikasi berbagai objek menggunakan gelombang radio, terdiri dari 2 bagian yaitu tag atau transponder dan reader. Elektronik Kartu Tanda Penduduk (eKTP) dapat digunakan sebagai RFID tag karena didalamnya terdapat chip yang menyimpan nomor ID unik, RFID reader digunakan untuk membaca nomor ID unik pada e-KTP. e-KTP juga merupakan benda yang sering dibawa kemana-mana pada saat bepergian. Alat ini juga memanfaatkan wireless sebagai sistem informasi kepada penghuni rumah apabila ada orang yang melakukan percobaan untuk membuka kunci pintu menggunakan e-KTP yang dimiliki orang tersebut. Wireless ini dihubungkan pada aplikasi android sebagai pemberi informasi, namun dapat berfungsi juga sebagai pengendali untuk membuka kunci pintu sesuai dengan instruksi yang diberikan. Selain itu juga, terdapat alarm (buzzer), Solenoid Door Lock, dan Led sebagai output dari alat ini yang berfungsi untuk mendukung proses kerja alat agar mampu bekerja dengan sebaik mungkin (Mahesa, Rahmawan, Rinharsah, \& Ariffin, 2019).

Berdasarkan latar belakang diatas maka dalam tugas akhir ini penulis mengambil judul "Smart Lock Door Menggunakan Akses e-KTP bebasis Internet of Things"

\section{Metode Penelitian}

Metode penelitian merupakan suatu mekanisme, teknik atau tata cara bagaimana suatu penelitian dilaksanakan. Metode penelitian dianggap sebagai seperangkat pendekatan menyeluruh untuk mengumpulkan data dan menganalisis masalah-masalah tertentu mencakup teknik dan alat. Desain penelitian yang digunakan dalam penelitian ini adalah True Experimental design, hal ini dikarenakan dalam desain ini peneliti harus dapat mengontrol semua variabel luar yang memepengaruhi jalannya experimen. Dengan demikian validitas internal dapat menjadi tinggi. Sumber data dan informasi penelitian ini diperoleh dengan menggunakan metode tertentu dan dipilah berdasarkan jenis data yang diperlukan.

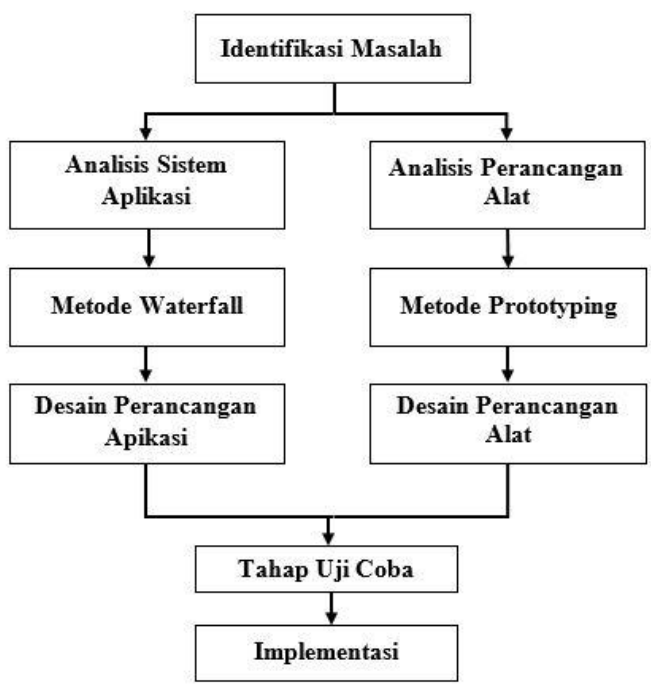

Gambar 1. Bagan Alur Metode penelitian

\section{Hasil dan Pembahasan}

Tahapan yang diperlukan dalam pembuatan suatu program yaitu menganalisa sistem yang telah ada, dimana analisa sistem merupakan proses mempelajari suatu sistem dengan cara menguraikan sistem tersebut kedalam elemen yang membentuknya.Selanjutnya mengidentifikasi dan mengevaluasi permasalahan- 
permasalahan yang terjadi serta kebutuhan yang diperlukan, sehingga dapat berjalan dengan baik.

\subsection{Implementasi \\ 3.1.1 Perakitan Prototipe Perangkat}

Untuk mendukung kerja sistem maka perlu dibuat sebuah prototype/replika berupa pintu ruangan yang dapat dibuka/ditutup. Penulis membuat prototype/replika sistem ini dengan menggunakan papan dari bahan PCB bekas dan juga memakai sterofoam. Penulis sengaja membuat prototype secara sederhana karena disini yang diibutuhkan hanya pembuktian mengunci atau tidaknya solenoid door lock pada saat ada interaksi dengan e-KTP. Bahan yang dibutuhkan hanya menggunakan sterofoam, papan fiber PCB untuk pintu, engsel kupu-kupu, dan pegangan pintu untuk membuka dan menutup pintu. Semua bahan digergaji sesuai dengan ukuran yang diperlukan. Untuk melubangi pintu bisa menggunakan pisau cutter. Bagian atas dan bawah disatukan dengan cara dibaud agar pondasi bawah kuat menopang replika. Berikut adalah tampilan pintu ketika sudah dipasangkan solenoid door lock :

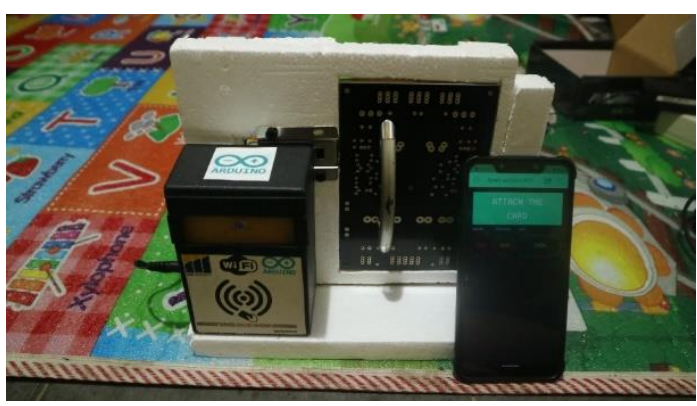

Gambar 2. Pintu Solenoid Door Lock

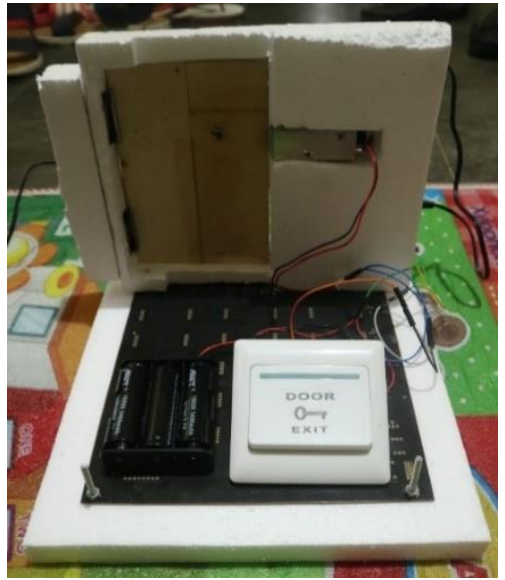

Gambar 3. Pembuka Kunci Pintu Push Button Dari Dalam

\subsubsection{Perakitan Prototipe Perangkat}

Setelah semua rangkaian telah selesai dihubungkan, maka langkah selanjutnya adalah melakukan pengujian terhadap sistem tersebut dengan menggunakan prototype pintu ruangan. Hal yang perlu dipastikan adalah semua komponen sudah terhubung dengan sempurna dan tidak mudah terlepas. Sehingga sistem tersebut akan bekerja secara optimal.

Untuk melakukan pengujian siapkan terlebih dahulu kartu yang belum terdaftar disistem. Berikut adalah tampilan awal disaat alat dihidupkan :

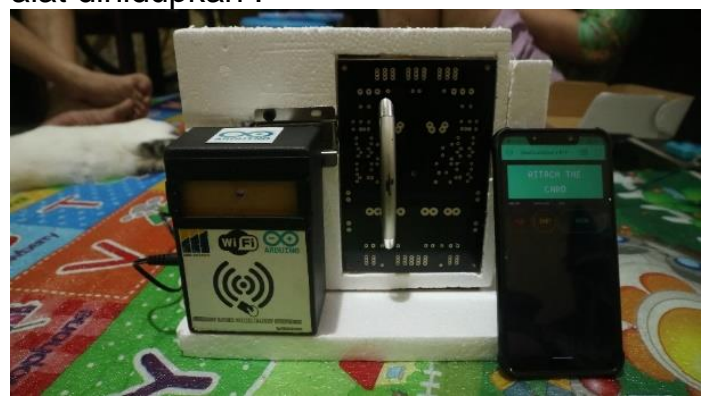

Gambar 4. Pengujian 1-Tampilan awal

Kemudian kita akan mencoba untuk mendaftarkan e-KTP yang sebelumnya tidak didaftarkan. Berikut tampilannya :

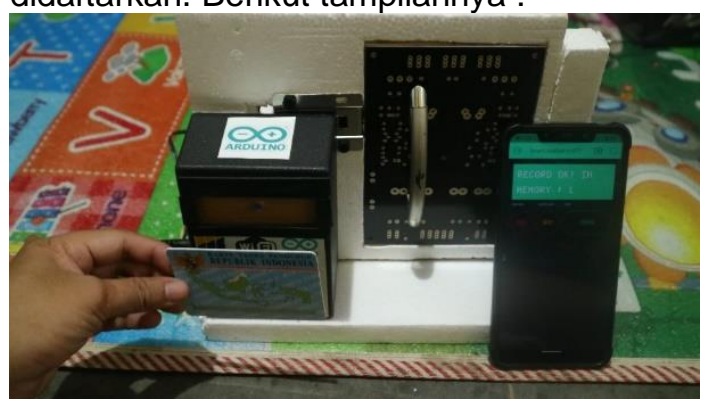

Gambar 5. Pengujian 2-On card

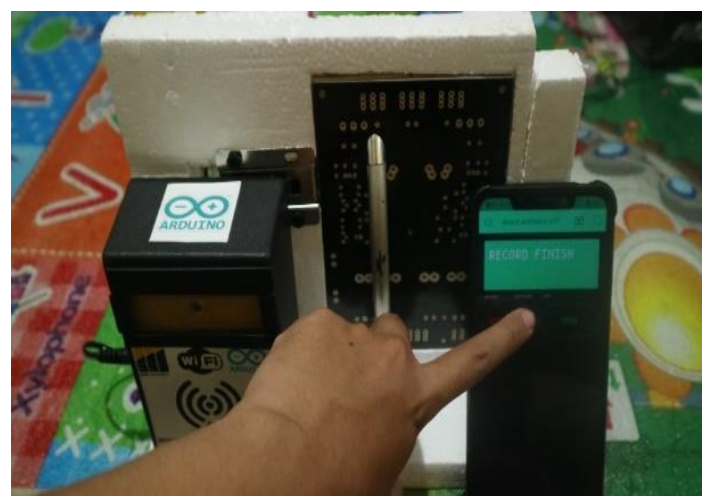

Gambar 6. Berhasil Menyimpan UID e-KTP Baru 
Setelah e-KTP terdaftar, kita akan uji coba untuk melakukan taping kartu. Berikut adalah tampilan pada saat taping kartu pada alat ini

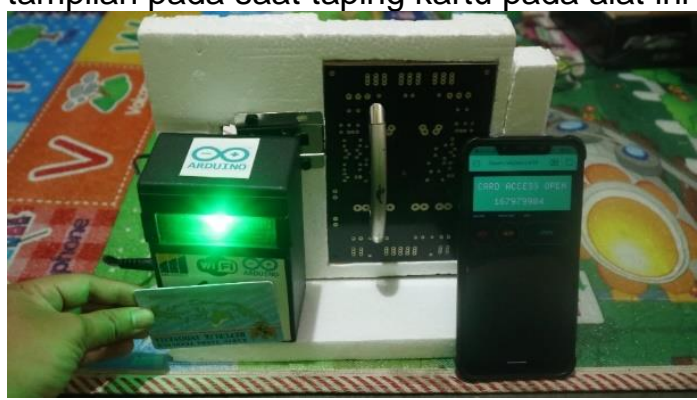

Gambar 7. Taping e-KTP Terdaftar

Setelah itu hasilnya solenoid door lock aktif dan pintu dapat dibuka. Berikut adalah tampilan pada saat solenoid door lock aktif dan pintu dapat dibuka:

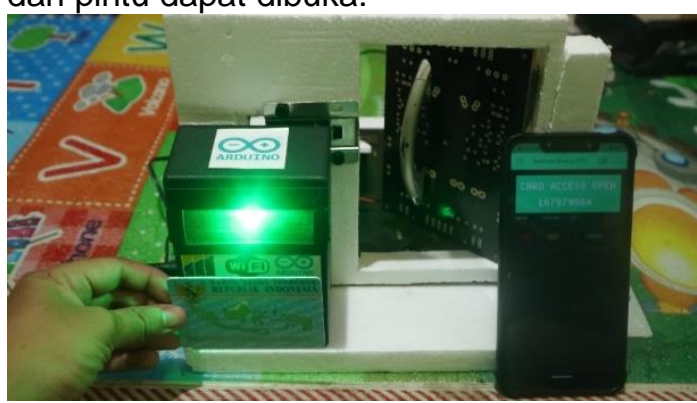

Gambar 8. Kunci Pintu Berhasil Terbuka Jika UID e-KTP belum terdaftar maka hasil nya lampu LED merah menyala,berikut adalah tampilan lengkapnya pada saat UID belum terdaftar. :

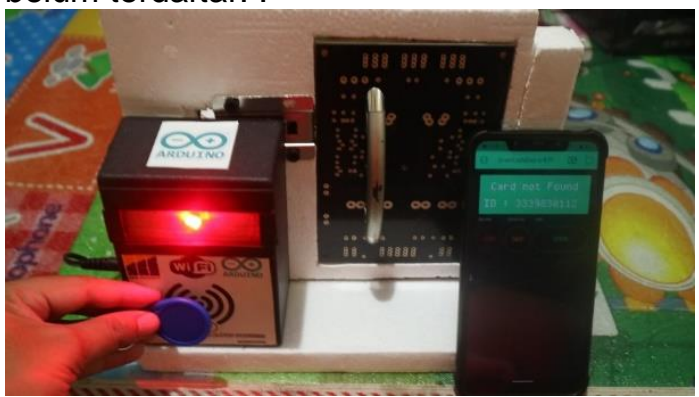

Gambar 9. Kunci Pintu Gagal di Akses Kunci pintu dapat di akses juga pada aplikasi Blynk dengan menekan tombol open. Berikut tampilan lengkapnya :

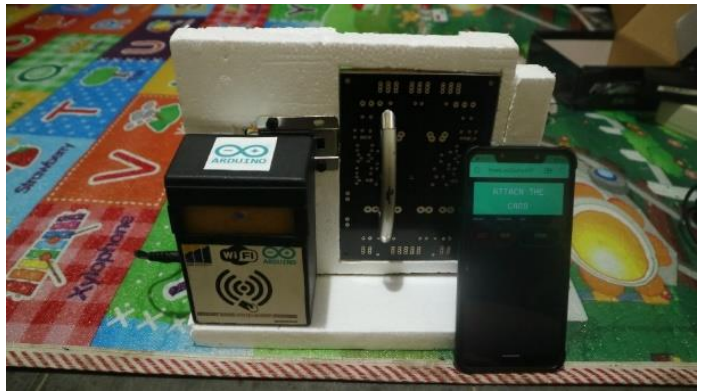

Gambar 10. Kunci Pintu Di Akses dari Aplikasi Blynk

\subsubsection{User Interface}

User interface merupakan salah satu faktor terpenting dalam membangun sebuah aplikasi. Tanpa persiapan dan perancangan yang matang, suatu aplikasi tertentu tidak bisa berjalan secara maksimal, bahkan bisa mengakibatkan user berpindah ke aplikasi lain. Desain antarmuka (interface) adalah desain masukan (input) yang akan digunakan untuk memasukan data ke dalam sistem. Berikut interface aplikasi "SMART LOCK DOOR MENGGUNAKAN AKSES e-KTP BERBASIS INTERNET OF THINGS".

A.User Interface Aplikasi Smart Lock Door e-KTP

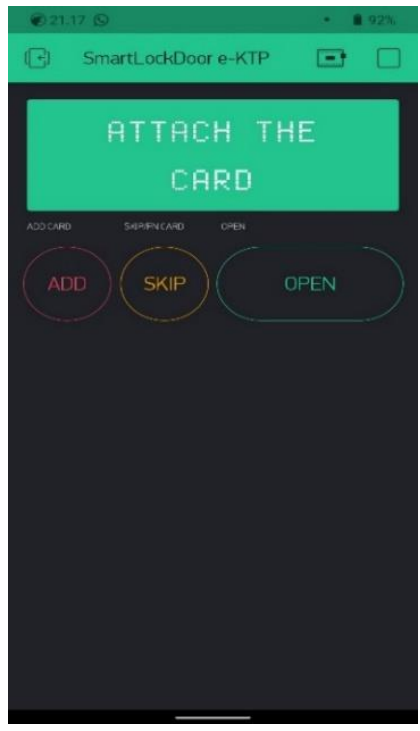

Gambar 11. User Interface Halaman Utama

Pertama user masuk akan menampilkan halam utama pada Gambar 11. User Interface Halaman Utama terdapat tombol Add, Skip dan Open. 


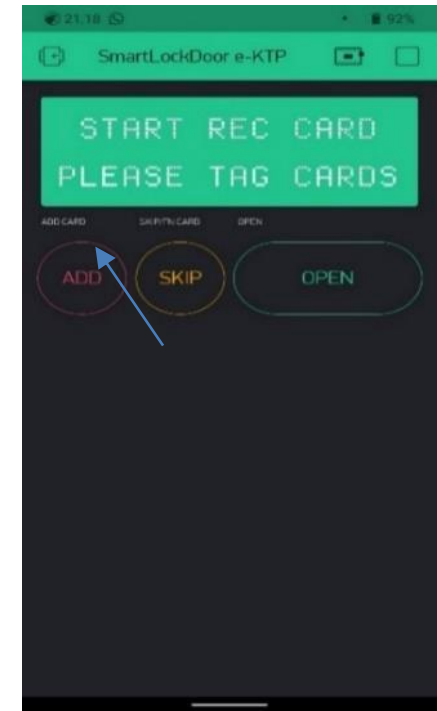

Gambar 12. Tampilan Tombol Add

Pada saat tombol Add ditekan maka akan muncul tampilan seperti pada Gambar 12. Tampilan Tombol Add.Tombol Add berfungsi untuk menyimpan UID (Unique Identifier Definition) pada e-KTP, Card Tag, atau Key Tag.

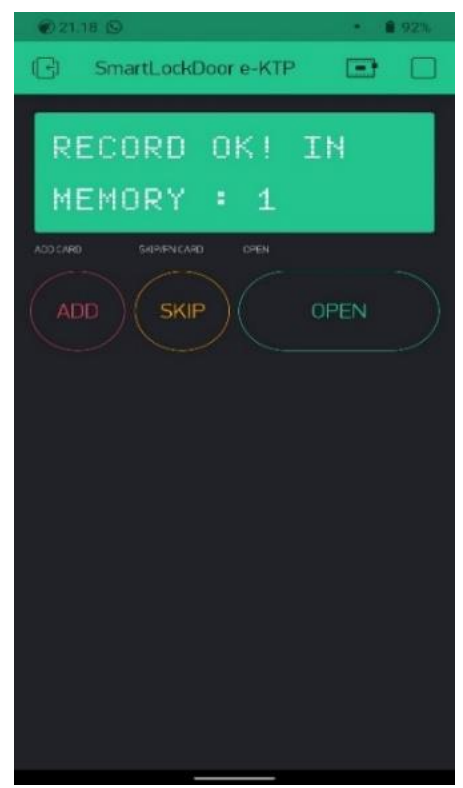

Gambar 13. Tampilan Berhasil Menambahkan UID Card

Pada Gambar 13. adalah tampilan apabila kita berhasil menambahkan UID card baru

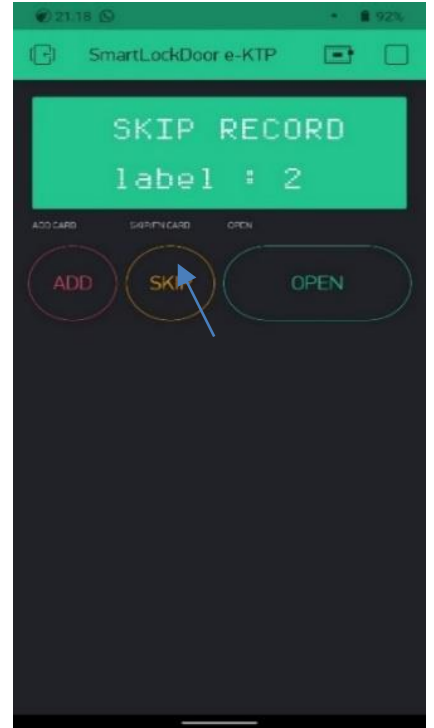

Gambar 14. Tampilan Melewati Apabila UID Sudah Di Tambahkan

Pada Gambar 14. adalah tampilan pada saat pengguna hanya menambahkan satu UID saja,maka pengguna menekan tombol SKIP untuk melewati label selanjutnya.

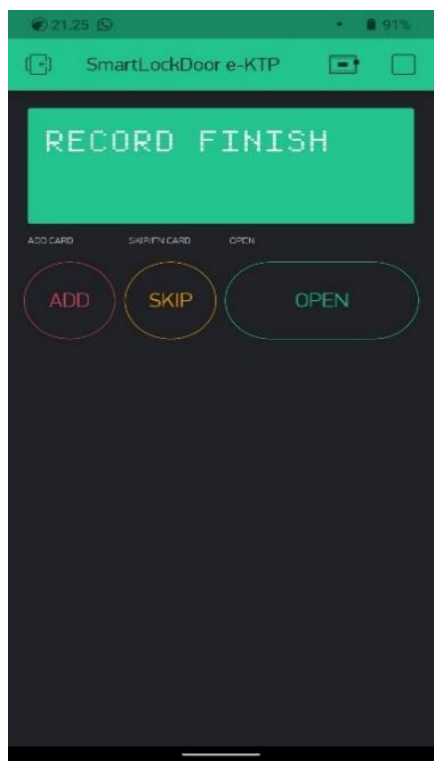

Gambar 15. Tampilan Selesai Menambahkan UID Card

Pada Gambar 15. adalah tampilan pada saat pengguna selesai menambahkan UID yang di inginkan. 


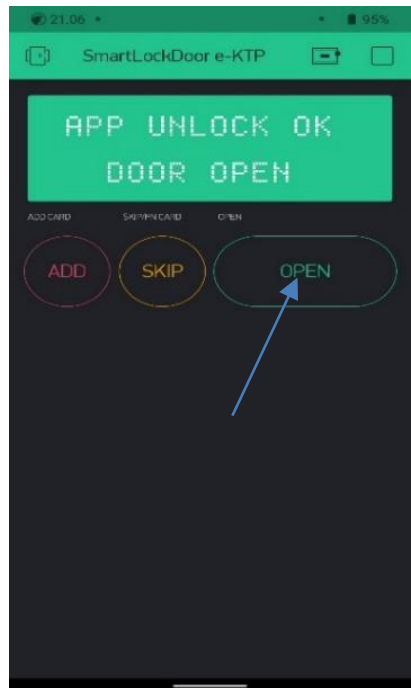

Gambar 16. Tampilan Menekan Tombol Open

Pada Gambar 16. adalah tampilan pada saat pengguna menekan tombol open pada aplikasi, maka akan muncul tampilan akses pintu kunci terbuka pada prototype alat tersebut.

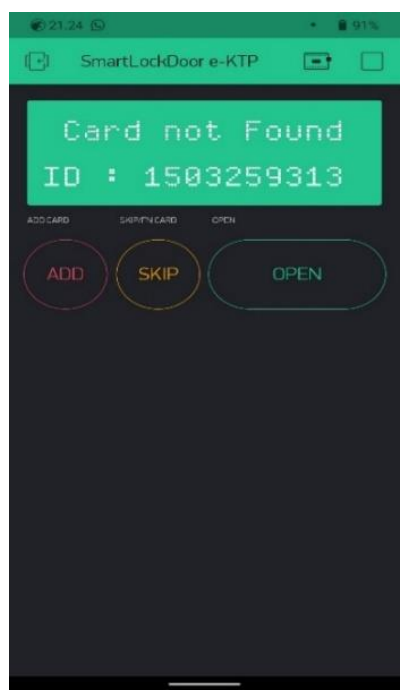

Gambar 17. Tampilan UID e-KTP Tidak Terdaftar

Pada Gambar 17. adalah tampilan jika UID pada alat tersebut belum di tambahkan,maka akan tampil UID card tidak ada atau belum terdaftar.

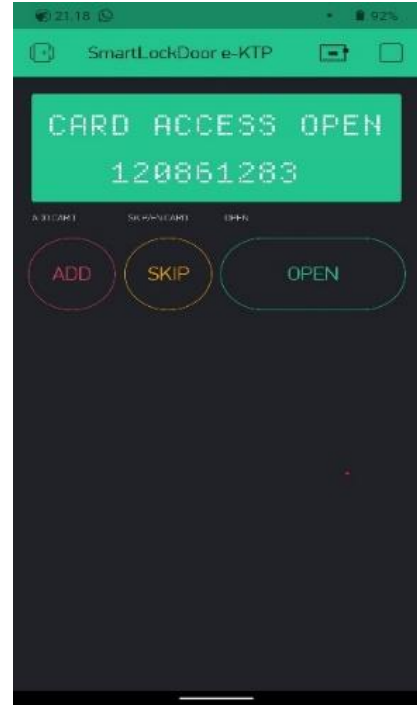

Gambar 18. Tampilan UID e-KTP Dapat Mengakases Pintu

Pada Gambar 18. adalah tampilan jika UID e-KTP pada alat tersebut sudah di tambahkan atau terdaftar,maka akan muncul tampilan akses kunci pintu terbuka.

\subsection{Uji Coba Perangkat Utama \\ 3.2.1 Uji Coba Black Box Pada Aplikasi Smart Lock Door e-KTP}

\section{A. Black Box Testing Add, Skip, Open}

Tabel 1. Jarak Baca Reader

\begin{tabular}{|c|l|l|l|c|c|}
\hline No. & $\begin{array}{l}\text { Skenario } \\
\text { Pengujian }\end{array}$ & Test Case & $\begin{array}{l}\text { Hasil yang } \\
\text { diharapkan }\end{array}$ & $\begin{array}{c}\text { Hasil } \\
\text { Pengujian }\end{array}$ & Kesimpulan \\
\hline 1. & $\begin{array}{l}\text { klik tombol } \\
\text { Add }\end{array}$ & $\begin{array}{l}\text { Muncul } \\
\text { tampilan } \\
\text { Start } \\
\text { Record Tag } \\
\text { Record OK! } \\
\text { Memory In } \\
=1\end{array}$ & $\begin{array}{l}\text { Sistem akan } \\
\text { menyimpan UID } \\
\text { e-KTP yang } \\
\text { didaftarkan }\end{array}$ & $\begin{array}{c}\text { Sesuai } \\
\text { harapan }\end{array}$ & Valid \\
& $\begin{array}{l}\text { Muncul } \\
\text { tampilan } \\
\text { Skip Record } \\
\text { Label : 2 } \\
\text { Record } \\
\text { Finish }\end{array}$ & $\begin{array}{l}\text { Sistem akan } \\
\text { menampilkan } \\
\text { jika hanya satu } \\
\text { UID e-KTP yang } \\
\text { ingin } \\
\text { didaftarkan. }\end{array}$ & $\begin{array}{l}\text { Sesuai } \\
\text { harapan }\end{array}$ & Valid \\
\hline 3. tombol \\
Open
\end{tabular}

\subsubsection{Uji Coba RFID Reader}

Pengujian RFID Reader ditest cara kerja antara RFID dengan e-KTP sehingga penulis mengetahui berapa jarak dan durasi baca data antara RFID dan e-KTP berfungsi.

\section{A.Pengujian Jarak Baca RFID}

Pengujian reader dilakukan dengan mengukur jarak baca data. Pengujian dari 
jarak reader membaca tag dapat dilihat pada tabel 1.

Tabel 1. Jarak Baca Reader

\begin{tabular}{|c|c|c|}
\hline No. & UID & $\begin{array}{c}\text { Jarak Baca } \\
(\mathrm{cm})\end{array}$ \\
\hline 1 & $\begin{array}{c}0441170 A \\
032 B 80\end{array}$ & $0-2,5$ \\
\hline 2 & 04826492 \\
& $552 A 80$ & $0-2,5$ \\
\hline 3 & 07343263 & $0-2,5$ \\
\hline 4 & $046 A 5912$ & $0-2,5$ \\
& $C 82 E 80$ & \\
\hline
\end{tabular}

\section{B.Pengujian Durasi RFID}

Pengujian dilakukan untuk mengetahui durasi lama baca yang dapat dijangkau oleh RFID.Pengujian dilakukan dengan meletakkan e-KTP tepat diatas RFID dengan posisi sejajar. e-KTP didekatkan perlahan - lahan menuju RFID reader dengan cara setiap $1 \mathrm{~mm}$ RFID tag menuju RFID, ditahan selama 2 detik untuk melihat respon apakah e-KTP telah terinduksi oleh antenna.

Tabel 2. Waktu Baca RFID Reader

\begin{tabular}{|c|c|c|}
\hline No. & UID & $\begin{array}{c}\text { Rata-Rata } \\
\text { Waktu Baca } \\
(S)\end{array}$ \\
\hline 1 & $\begin{array}{c}0441170 A \text { 03 } \\
2 B 80\end{array}$ & 0,69 \\
\hline 2 & $\begin{array}{c}04826492 \text { E5 } \\
2 A 80\end{array}$ & 0,71 \\
\hline 3 & 07343263 & 0,68 \\
\hline 4 & $046 A 5912$ C8 \\
& $2 E 80$ & 0,70 \\
\hline
\end{tabular}

\section{C.Pengujian Pembacaan RFID}

Pengujian dilakukan untuk mengetahui jarak baca yang dapat dijangkau oleh RFID reader. Pengujian dilakukan dengan meletakkan e-KTP tepat diatas RFID reader dengan posisi sejajar. e-KTP didekatkan perlahan-lahan menuju RFID reader dengan cara setiap $1 \mathrm{~mm}$ e-KTP menuju RFID reader, ditahan selama 2 detik untuk melihat respon apakah e-KTP telah terinduksi oleh antenna.

Tabel 3. Pembacaan RFID Reader

\begin{tabular}{|c|c|c|}
\hline No. & UID & Respon RFID \\
\hline 1 & $0441170 A$ & Terbaca \\
& $032 B 80$ & \\
\hline 2 & 04826492 & Terbaca \\
& $E 52 A 80$ & \\
\hline 3 & 07343263 & Terbaca \\
\hline 4 & $046 A 5912$ & Terbaca \\
& C8 2E 80 & \\
\hline
\end{tabular}

Dari tabel 1. dan 2. dan 3. dapat dinyatakan bahwa reader dapat membaca e-KTP dengan baik. Kemampuan jarak baca reader juga cukup baik, karena RFID tag yang digunakan pasif, sehingga jarak $2,5 \mathrm{~cm}$ sudah cukup baik untuk reader dalam membaca e-KTP.

\section{Kesimpulan}

Telah dirancang dan dibangun Smart Lock Door Menggunakan Akses e-KTP bebrbasis Internet Of Things. Dalam pemrograman menggunakan Arduino IDE v1.8.5 dengan bahasa pemrograman bahasa C. Komponen Solenoid Lock Door 12 volt sebagai pengunci pintu. Komponen RFID sebagai pembaca e-KTP dan Smart Card. Komponen Buzzer dan LED sebagai indikator tanda e-KTP terdaftar atau tidak. Komponen Push Button sebagai pembuka kunci pintu dari dalam rumah. Komponen Relay sebagai saklar solenoid. Aplikasi Blynk menampilkan keterangan dan juga bisa membuka pintu dari aplikasi. Aplikasi Blynk dapat mendaftarkan e-KTP yang ingin ditambahakan untuk bisa mengakses solenoid door lock. Sistem keamanan pintu menggunakan e-KTP dapat dibuat dan dioperasikan dengan menggunakan mikrokontroler NodeMCU Lolin V3 sebagai pusat kendali rangkaian dan diprogram menggunakan software IDE Arduino. NodeMCU juga terhubung dengan jaringan internet melalui wireless yang akan terhubung ke aplikasi Blynk pada Smartphone. Sistem keamanan pintu menggunakan e-KTP ini mampu membaca UID e-KTP dengan jarak maksimal $2,5 \mathrm{~cm}$ dengan sensor RFID reader MFRC522 yang memiliki frekuensi $13.56 \mathrm{MHz}$ diletakkan dalam box duradus dengan tebal $1 \mathrm{~cm}$.

\section{Referensi}

Kumar, D. M., Hanumanthappa, D. M., Kumar, D. T. V. S., \& Ojha, M. A. K. (2016). Android Based Smart Door Locking System with Multi User and Multi Level Functionalities. International Journal of Advanced Research in Computer and Communication Engineering, 5, 115-118.

Kumar, P., \& Pati, U. C. (2016). Arduino and Raspberry $\mathrm{Pi}$ based Smart Communication and Control of Home Appliance System. International Conference on Green Engineering and Technologies (IC-GET), 1-6. 
Kusriyanto, M., \& Putra, B. D. (2017). Smart Home Using Local Area Network (Lan) Based Arduino Mega 2560. Proceedings - ICWT 2016: 2nd International Conference on Wireless and Telematics 2016, 127-131. https://doi.org/10.1109/ICWT.2016.787 0866

Mahesa, A. T., Rahmawan, H., Rinharsah, A., \& Ariffin, S. (2019). Sistem Keamanan Brankas Berbasis Kartu Ektp. Jurnal Teknologi \& Manajemen Informatika, 5, 1-9.

Mubarok, A., Sofyan, I., Rismayadi, A. A., \& Najiyah, I. (2018). Sistem Keamanan Rumah Menggunakan RFID, Sensor PIR dan Modul GSM Berbasis Mikrokontroler. JURNAL INFORMATIKA, 5, 137-144.

Padeli, Febriyanto, E., \& Suprayogi, D. (2019). PROTOTYPE SISTEM SMART LOCK DOOR DENGAN TIMER DAN FINGERPRINT SEBAGAI ALAT AUTENTIKASI BERBASIS ARDUINO UNO. Jurnal Informatika Vol.19, No.1, 1, 10-19.

Patil, V. A., Khilari, D. S., \& Sheelavant, A. S. (2016). SMART LOCK. International Journal of Engineering Applied Sciences and Technology, 2016 Vol. 1, $1,120-129$.

166-176.

Ratih, N. D., Setiawan, B. A., \& Triono, J. (2019). PEMANFAATAN E-KTP UNTUK KEAMANAN RUMAH DAN LINGKUNGAN RUKUN TETANGGA (RT). Seminar Nasional Sistem Informasi 2019, 1932-1939.

Wendanto, W., Salim, D. J. N., \& Putra, D. W. T. (2019). Rancang Bangun Sistem Keamanan Smart Door Lock Menggunakan E-KTP (Elektronik Kartu Tanda Penduduk) Dan Personal Identification Number Berbasis Arduino Mega R3. GO INFOTECH: JURNAL ILMIAH STMIK AUB, 25, 133-142.

Ye, M., Jiang, N., Yang, H., \& Yan, Q. (2017). Security Analysis of Internet-of-Things: A Case Study of August Smart Lock. 2017 IEEE Conference on Computer Communications Workshops (INFOCOM WKSHPS): MobiSec 2017: Security, Privacy, and Digital Forensics of Mobile, 499-504. 